EETP Vol. 14, 2019, №. 3(53)

ISSN 1896-2327 / e-ISSN 2353-7787

DOI: $10.35765 /$ eetp.2019.1453.02

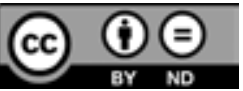

Nadesłano: 26.04.2019

Zaakceptowano: 12.07.2019

Sugerowane cytowanie: Sosnowska J. (2019). Proces przemian w wychowaniu przedszkolnym w Łodzi po 1918 roku w świetle źródeł archiwalnych, „Edukacja Elementarna w Teorii i Praktyce", vol. 14, nr 3(53), s. 27-46. DOI: 10.35765/eetp.2019.1453.02

\title{
Proces przemian w wychowaniu przedszkolnym w Łodzi po 1918 roku w świetle źródeł archiwalnych
}

\author{
The Transformation Process in Preschool Education \\ in Łódź after 1918 in the Light of Archive Materials
}

\section{SŁOWA KLUCZOWE ABSTRAKT}

wychowanie Celem badań w niniejszym szkicu była próba ukazania przeobraprzedszkolne żeń w dziedzinie wychowania przedszkolnego w Łodzi po odzyskaw Łodzi, placówki niu niepodległości w 1918 r. Problem badawczy stanowiła kwestia przedszkolne różnych wyznań, badania archiwalne, oświata w Łodzi po 1918 roku, Zarząd organizowania edukacji przedszkolnej przez łódzki samorząd, kiedy jedynymi placówkami dla dzieci w wieku przedszkolnym w mieście były ochronki społeczne, prowadzone przez organizacje filantropijne, parafie i społeczności różnych wyznań oraz osoby prywatne. Innym zagadnieniem było to, jakie impulsy i okoliczności zadecydom. Łodzi wały o zorganizowaniu pierwszej i 12 kolejnych miejskich placówek przedszkolnych w Łodzi. W poszukiwaniu odpowiedzi sięgnięto do materiału źródłowego stanowiącego zasób Archiwum Państwowego w Łodzi, poddając analizie badawczej zgromadzone tam dokumenty (głównie Wydziału Oświaty i Kultury Zarządu m. Łodzi). W wyniku badań stwierdzono, że w roku 1922 zarząd miejski objął nadzorem pedagogicznym około 15 społecznych placówek przedszkolnych, ale kontrole ich pracy wychowawczej wykazywały wiele uchybień. Ta kwestia stała się głównym impulsem do podjęcia przez łódzki samorząd działań ukierunkowanych na zakładanie własnych instytucji wychowania przedszkolnego. Wniosek z badań: przeobrażenia, jakie 
można odnotować w obszarze edukacji przedszkolnej po 1918 r., to przede wszystkim próba ujednolicenia działalności pedagogicznej ochronek społecznych o różnym statusie, podniesienie poziomu pracy wychowawczej przez systematyczny nadzór i doskonalenie metodyczne oraz zapoczątkowanie - poprzez powołanie w 1924 r. pierwszego miejskiego przedszkola - sieci placówek przedszkolnych w mieście.

\section{KEYWORDS ABSTRACT}

preschool education in Łódź, preschool institutions of various denominations, archive research, education in Łódź after 1918, Board of the city of Łódź
The purpose of the research described in this work was to attempt to show transformations of pre-school education in Łódź after Poland had regained independence in 1918. The research was focused on the issue of organising pre-school education by Łódź local government, when the only institutions for pre-school children in Łódź included social shelters run by charitable organizations, parishes, communities of various denominations, and private individuals. Others issues included the stimuli and circumstances which decided about the organization of the first and the subsequent twelve municipal kindergartens in Łódź. The research was based on source materials kept in the National Archive in Łódź; the analysis included documents collected there (mainly documents of the Department of Education and Culture of the Municipal Board of Łódź). As a result, it was concluded that in 1922 the Board started pedagogical supervision of app. 15 community kindergartens and the inspection of their operation revealed many oversights. That issue became the main reason for action taken by the Łódź local government aimed at opening municipal pre-school institutions. The research has led to the conclusion that the transformations which could be observed in pre-school education after 1918 include, most of all, an attempt to standardize the pedagogical aspects of the operation of community shelters with a various status and to increase the level of education through regular supervision and methodological improvement, as well as starting a network of kindergartens in the city by opening the first municipal kindergarten in 1924.

\section{Zagadnienia wstępne}

Wraz z odzyskaniem przez państwo polskie niepodległości w 1918 r. nowe idee i postulaty w dziedzinie oświaty, edukacji, wychowania i opieki nad dzieckiem formułowane przez teoretyków i praktyków wychowania jeszcze w okresie I wojny światowej - mogły znaleźć szersze pole w dyskusji społecznej i wpisać się w nowo tworzoną politykę oświatową młodego państwa. Próbę wypracowania koncepcji systemu edukacji narodowej podjęli przedstawiciele organizacji nauczycielskich, działacze 
oświatowi i reprezentanci władz państwowych w kwietniu 1919 r. podczas kilkudniowego ogólnopolskiego zjazdu zwanego Sejmem Nauczycielskim (Mauersberg 1980: 139-145; Jamrożek 2009: 133-135).

Przedmiotem tamtych obrad stały się również problemy wychowania przedszkolnego, wprowadzone do dyskusji przez powołaną wówczas Sekcję Wychowania Przedszkolnego (Sekcja II) (Bobrowska-Nowak 1978: 256-257). Ponownie podczas zjazdu - bowiem postulaty w tym obszarze wysuwano już w 1917 i 1918 r. (Wróbel 1967: 26; Miąso 1980: 99) ${ }^{1}$ - uwypuklono znaczenie ochron/ochronek w koncepcji trzystopniowego systemu szkolnictwa i siedmioklasowej szkoły powszechnej, domagając się powiązania tych instytucji ze szkołą, tak by miały one status przygotowujących dzieci do edukacji szkolnej. Oprócz tego, postulowano, aby zasada powszechnej dostępności do edukacji, którą odnośnym aktem prawnym wprowadzono w lutym 1919 r., mogła obowiązywać również w ochronach (propozycja dotyczyła dzieci co najmniej dwu ostatnich roczników przed ukończeniem siedmiu lat) (O polską szkołę 1920: 237). Te i inne cenne postulaty (Bobrowska-Nowak 1978: 258)² zostały jednogłośnie przyjęte przez Sejm Nauczycielski, stając się nawet bazą do wprowadzenia zmian w obszarze wychowania przedszkolnego w Polsce, ale nieodległa rzeczywistość dowiodła, że nie wszystkie znalazły zrozumienie i umocowanie na płaszczý́nie administracyjno-prawnej i organizacyjnej, a niektóre, do końca okresu międzywojennego, pozostały wyłącznie w sferze deklaratywnej. Można przypuszczać, że o wiele istotniejsze w tym czasie okazały się problemy kształtowania ustroju polityczno-społecznego państwa, wdrożenie jednolitego systemu prawno-administracyjnego i walutowego, formowanie granic czy stopniowa odbudowa gospodarki ze zniszczeń wojennych, a w sferze oświaty - tworzenie podstaw szkolnictwa powszechnego i średniego, aniżeli troska o świadome wychowanie dziecka w wieku przedszkolnym.

Z niskiej pozycji edukacji przedszkolnej w ówczesnym systemie oświatowym zdawała sobie sprawę Maria Weryho-Radziwiłłowiczowa, pedagog i pisarka, jedna z prekursorek wychowania przedszkolnego w Polsce, która we własnym periodyku³, zainicjowanym z myślą o wychowawczyniach, stwierdziła, iż wychowanie przedszkolne jest „kopciuszkiem pedagogicznym”, a „społeczeństwo otacza szkołę należytą opieką przedszkole natomiast jest w znacznie mniejszym stopniu przedmiotem troski ogólnej...” (Stowo wstępne 1925: 1). Nie można jednak mówić o braku inicjatyw ze strony organów administracji państwowej, bowiem przy Ministerstwie Wyznań Religijnych i Oświecenia Publicznego powołano specjalny Referat Wychowania Przedszkolnego

\footnotetext{
Podczas dwóch zjazdów nauczycielskich w latach 1917 i 1918 w Krakowie ustalono podstawowe zadania ochron/ochronek, podkreślając ich funkcje opiekuńcze, ale także wychowawcze i edukacyjne - istotne w przygotowaniu dzieci do podjęcia nauki w szkole.

Sekcja Wychowania Przedszkolnego zgłosiła wówczas osiem wniosków.

3 Czasopismo „Wychowanie Przedszkolne” ukazujące się w latach 1925-1939.
} 
(Wróbel 1967: 42-43) ${ }^{4}$, który do momentu jego likwidacji w 1926 r. uregulował wiele kwestii w obszarze wychowania przedszkolnego. Niemniej, od władz oświatowych oczekiwano konkretnych unormowań legislacyjnych, umożliwiających tworzenie, na terenie całego kraju, sieci placówek przedszkolnych działających profesjonalnie.

W przedsięwzięcia podejmowane w dziedzinie szeroko rozumianej oświaty, zwłaszcza w początkowym okresie niepodległego państwa, aktywnie włączyły się samorządy miejskie. Po pierwsze - realizowały wytyczne organów centralnych, po drugie - znały realia i potrzeby środowiska lokalnego. Wkrótce po odzyskaniu niepodległości władze polskie wydały Dekret o wyborach do Rad Miejskich na terenie b. Królestwa Kongresowego z 13 grudnia 1918 r. oraz, po dwóch miesiącach, Dekret o samorzadzie miejskim z 4 lutego 1919 r. (Księga pamiątkowa 1930: 27; Wasiak 1980: 55). Ostatni z dokumentów regulował podstawowe prawa i obowiązki wyborców oraz samorządu, określał kompetencje i sposób urzędowania rady miejskiej, prawa i obowiązki radnych. Wyznaczał organizację wewnętrzną i kompetencje magistratu, ale równocześnie wprowadzał nadzór administracji państwowej nad miastami (Wasiak 1980: 58)5. Zadania mające na celu rozwój oświaty i kultury (prowadzenie lub subsydiowanie odnośnych instytucji), ochronę zdrowia publicznego czy zapewnienie opieki społecznej mieszkańcom na danym terenie wpisano właśnie w zakres kompetencji związków komunalnych ${ }^{6}$. Można nawet zaryzykować tezę, że w większych aglomeracjach, jak np. w Łodzi, rozwój szeroko rozumianej oświaty, podobnie jak innych dziedzin życia społecznego, związany był z powstaniem i funkcjonowaniem lokalnego samorządu, decyzjami administracyjnymi, a przede wszystkim z finansami, będącymi w jego dyspozycji.

Problemy wychowania przedszkolnego w Łodzi nie znalazły się w centrum głównych zagadnień społecznych nowo wybranych w 1919 r. władz miejskich, nie uznano ich wtedy za priorytetowe, a nawet - nadzór nad istniejącymi ochronkami społecznymi (samorząd nie posiadał własnych ochron) zlecono Wydziałowi Dobroczynności Publicznej Magistratu m. Łodzi i specjalnej Komisji Opieki Społecznej, a nie

\footnotetext{
4 Kierownictwo referatu powierzono M. Weryho-Radziwiłłowiczowej. Jednostka zajęła się m.in.: reorganizacją i ustaleniem jednolitych form organizacyjnych istniejących już placówek, wprowadzeniem jednolitych programów i metod pracy pedagogicznej w instytucjach przedszkolnych, zapewnieniem placówkom istniejącym i nowo powstałym wykwalifikowanej kadry pedagogicznej. Referat obejmował jednak tylko rejony centralnej Polski.

5 Uprawnienia samorządów wynikające z dekretów wydanych w latach 1918-1919 były stopniowo ograniczane na rzecz administracji państwowej. Jej nadzór nad samorządem został uregulowany w 1928 r., wzmocniony w 1933 r. Według J. Wasiak, podział kompetencji między samorządem a administracją państwową był przedmiotem przetargów przez cały okres międzywojenny, z tym że od lat 30 . XX w. zawsze racja była po stronie administracji państwowej.

6 Inne - „własne” obowiązki struktur lokalnych to: zarządzanie majątkiem gminy, zakładanie i utrzymywanie dróg, mostów i środków komunikacyjnych, sprawy aprowizacyjne oraz popieranie miejscowego przemysłu, rzemiosła i handlu.
} 
Wydziałowi Szkolnictwa odpowiadającemu za sferę oświatową ${ }^{7}$ Na plan pierwszy wysunięto wówczas likwidację analfabetyzmu, propagowanie czytelnictwa i rozwój bibliotek, ale przede wszystkim podjęto decyzję o wprowadzeniu w mieście - w środowisku, w którym dominowała słabo wykształcona ludność robotnicza (Rzepkowski 2008: 103-104) ${ }^{8}$ - powszechnego nauczania dla dzieci w wieku 7-14 lat (Nartonowicz-Kot 1985: 6). Warto podkreślić, że łódzki samorząd jako pierwszy w kraju przystąpił do tych prac i już po kilku latach zakończyły się one sukcesem (Smolik 1929: 4). Zasadniczy krok w dziedzinie wychowania i edukacji dziecka w wieku przedszkolnym uczyniono natomiast $\mathrm{w}$ Łodzi $\mathrm{w}$ połowie lat 20. XX w., wtedy bowiem powołano do życia pierwszą miejską placówkę przedszkolną i tym samym wychowaniu przedszkolnemu w mieście próbowano nadać nowy kierunek pedagogiczny. Do tego jednak czasu, a więc do 1924 r., miejski samorząd, jak nadmieniono, nie posiadał własnych ochronek, a opieka władzy lokalnej nad dzieckiem w wieku przedszkolnym wyrażała się wyłącznie w formie subsydiowania ochronek chrześcijańskich i żydowskich ${ }^{9}$ należących do instytucji społeczno-dobroczynnych różnych wyznań i narodowości ${ }^{10}$. Zmiany, jakie w ciągu kilku kolejnych lat nastąpiły w wychowaniu przedszkolnym w Łodzi, musiały być dość znaczące, a przede wszystkim dostrzegalne z dalszej perspektywy, gdyż Zofia Żukiewiczowa, kierowniczka Sekcji Wychowania Przedszkolnego Zarządu Miejskiego w Warszawie, z racji obchodów 15-lecia istnienia placówek przedszkolnych w Polsce, stwierdziła, na łamach czasopisma „Przedszkole”, że wśród samorządów przodujących w podejmowaniu cennych działań na rzecz wychowania przedszkolnego znajduje się samorząd Łodzi (obok warszawskiego i lwowskiego oraz

\footnotetext{
Nowe władze miejskie, na czele z prezydentem Aleksym Rżewskim, rozpoczęły działalność w tym obszarze od ustalenia wykazu instytucji społecznych o różnorodnym profilu pomocy dzieciom (ochronki, sierocińce, domy schronienia), funkcjonujących w mieście i dotowanych finansowo jeszcze w czasie I wojny światowej. Przedstawiciele Wydziału Oświaty i Kultury komunikowali nawet Magistratowi, że „nie subsydiują żadnych instytucji opieki społecznej”; ochronki traktowano wówczas jako placówki opiekuńcze. Archiwum Państwowe w Łodzi (APŁ), Akta miasta Łodzi (AmŁ), Wydział Oświaty i Kultury (WOiK), sygn. 16837: Opieka nad dziatwą 1917-1921, karta (k.) 3 Wyciąg z posiedzenia Magistratu m. Łodzi z dn. 16 VII 1919; k. 6-7 Pismo Wydziału Szkolnictwa do Komisji Opieki Społecznej Wydziału Dobroczynności Publicznej z dn. 24 VII 1919.
}

8 W świetle danych pochodzących ze spisu w 1921 r. społeczeństwo łódzkie było słabo wykształcone: wyższe wykształcenie posiadało zaledwie $0,8 \%$ ogółu ludności, zawodowe średnie i niższe - 0,7\%, z wykształceniem początkowym było $46,6 \%$, domowym - 14,7\%. Znaczną grupę stanowili analfabeci $-20 \%$.

9 W 1922 r. z kasy miejskiej - za pośrednictwem Wydziału Opieki Społecznej (wcześniej Wydziału Dobroczynności Publicznej) przekazywano dotację finansową około 30 społecznym ochronkom/ochronom oraz placówkom, takim jak: sierocińce/domy sierot, przytułki, domy wychowawcze, gdzie mieszkały dzieci w wieku przedszkolnym. APŁ, AmE, Wydział Opieki Społecznej (WOS), sygn. 570: Instytucje dobroczynne 1922-1923, k. 23-24.

10 W 1921 r. Łódź zamieszkiwało 451974 osób; dominowała ludność polska (61,9\%), a więc rzymskokatolicka, druga pod względem liczebności była społeczność żydowska (30,7\%), a następnie niemiecka $(7,0)$, czyli głównie ewangelicka. Nieznaczny odsetek $(0,3 \%)$ stanowiły inne nacje. 
dwóch powiatowych - częstochowskiego i będzińskiego) (Żukiewiczowa 1933/34: 39; Żukiewiczowa 1934/35: 45-46).

Z punktu widzenia badań nad wychowaniem przedszkolnym w Łodzi w okresie międzywojennym istotnym elementem, ale i pytaniem badawczym, pozostaje kwestia organizowania edukacji przedszkolnej w mieście po 1918 r., stosunku łódzkich władz samorządowych do zarządów jako organów prowadzących placówki społeczne, jakości edukacji przedszkolnej w tych instytucjach, komunikowania się z zarządami oraz ochroniarkami, i wreszcie impulsów, które zadecydowały o zorganizowaniu pierwszego, a - z czasem - 12 kolejnych przedszkoli miejskich w Łodzi. Odpowiedź na te i inne zagadnienia może przynieść analiza materiału źródłowego stanowiącego zasób Archiwum Państwowego w Łodzi. Na podstawie dokumentów zawartych głównie w zbiorze „Akta miasta Łodzi - Wydział Oświaty i Kultury” podjęto w niniejszym szkicu próbę ukazania procesu przemian, jakie nastąpiły w łódzkiej edukacji przedszkolnej po odzyskaniu niepodległości (Szczepańska, 2000: 116-129; Sosnowska 2013: 66-79; Sosnowska 2014: 281-306; Sosnowska 2016: 281-297).

\section{Placówki wychowania przedszkolnego w Łodzi u progu niepodległości}

Kwestia opieki nad dzieckiem w wieku przedszkolnym pozostawała w Łodzi do 1918 r. w gestii sektora społecznego: filantropijnego, charytatywnego i prywatnego (Sosnowska 2017: 95, tabela 7). Łódź była miastem wieloetnicznym, stąd instytucje typu ochronki i ochrony ${ }^{11}$ prowadzone były - jak już pisano - przez organizacje dobroczynne, Kościoły, parafie, fabryki, związki i społeczności różnowyznaniowe. U progu 1919 r. działało w Łodzi około 30 ochron/ochronek należących do sektora społecznego, w których przebywały dzieci w wieku od 3-4 do 6-8 lat. Należy nadmienić, że tego typu instytucje pełniły głównie funkcje opiekuńczo-wychowawcze, z akcentem na opiekę (pewnym wyjątkiem były ochronki żydowskie (Sosnowska 2017: 395-396, 400, 402-406, 430-432), zapewniały dzieciom ciepły posiłek i umożliwiały kilkugodzinny pobyt podczas pracy zarobkowej rodziców, oprócz tego - w miarę możliwości finansowych danej organizacji - zaopatrywały wychowanków w odzież i obuwie.

W świetle danych Wydziału Statystycznego Magistratu m. Łodzi zebranych na początku 1918 r. liczba dzieci w wieku do lat siedmiu wynosiła 44693 dziewcząt i chłopców (13,1\% ogółu łodzian) (Goerne 1919: 27, tab. 3), a liczba uczęszczających

\footnotetext{
11 W materiale archiwalnym określenia typu „ochrona” i „ochronka” występują zamiennie; zdarzało się, że w dokumentacji dotyczącej ochron prywatnych i społecznych wykazywano dzieci starsze niż siedmioletnie, a w ochronkach - dzieci młodsze niż trzyletnie. APŁ, AmŁ, WOS, sygn. 18519: Sprawozdania Łódzkiej Miejscowej Rady Opiekuńczej 1917, k. 23-435.
} 
wówczas do ochronek społecznych kształtowała się na poziomie 5105 dzieci (tabela 1), co pozwala na konkluzję, że istniejące w mieście ochronki nie mogły zaspokoić sporych $-\mathrm{z}$ uwagi na liczebną przewagę ludności robotniczej, a więc potrzebującej zorganizowania opieki nad dzieckiem - potrzeb w tym zakresie.

Tabela 1. Dzieci w ochronkach w Łodzi w styczniu 1918 r.

\begin{tabular}{|c|c|c|c|c|}
\hline \multirow{2}{*}{$\begin{array}{c}\text { Ochronki według } \\
\text { wyznania dla dzieci: }\end{array}$} & Dziewczęta & Chłopcy & Razem & $\begin{array}{c}\text { Przeciętna } \\
\text { liczba dzieci } \\
\text { uczęszczających } \\
\text { do ochronek na } \\
\text { 1000 mieszkańców } \\
\text { danego wyznania }\end{array}$ \\
\cline { 2 - 5 } & 1479 & 1482 & 2961 & 18 \\
\hline $\begin{array}{c}\text { Rzymskokatolickich } \\
\text { (i pozostałych wyznań } \\
\text { chrześcijańskich) }\end{array}$ & 469 & 429 & 891 & 21 \\
\hline Religii mojżeszowej & 1045 & 188 & 1253 & 9 \\
\hline Ogółem & 2989 & 2099 & 5105 & 15 \\
\hline
\end{tabular}

Źródło: Goerne 1919: 41, tab. 6.

Wraz ukonstytuowaniem się nowych władz samorządowych kwestię opieki nad dziećmi przebywającymi w ochronkach społecznych powierzono, jak nadmieniono, jednej z miejskich agend, mianowicie Wydziałowi Dobroczynności Publicznej (od 1921 r. był to Wydział Opieki Społecznej). Jego przedstawiciele, pochłonięci zadaniami związanymi z zapewnieniem, po okresie wyniszczającej wojny, niezbędnej opieki socjalnej wielu mieszkańcom miasta (dożywianie, zaopatrywanie w opał, poszukiwanie dachu nad głową, umieszczanie w domach schronienia), nie zajęli się kwestią wychowania przedszkolnego, nawet nie monitorowali działalności ochronek społecznych. Ich rola ograniczała się do przekazywania comiesięcznych dotacji pieniężnych, głównie na dożywianie dzieci w tych instytucjach. W początkach $1922 \mathrm{r}$. dotowano 20 placówek mających status ochron/ochronek, w których przebywały dzieci w wieku 4-7 lat(tabela 2). 
Tabela 2. Ochronki/ochrony społeczne dotowane przez Magistrat m. Łodzi w 1922 r.

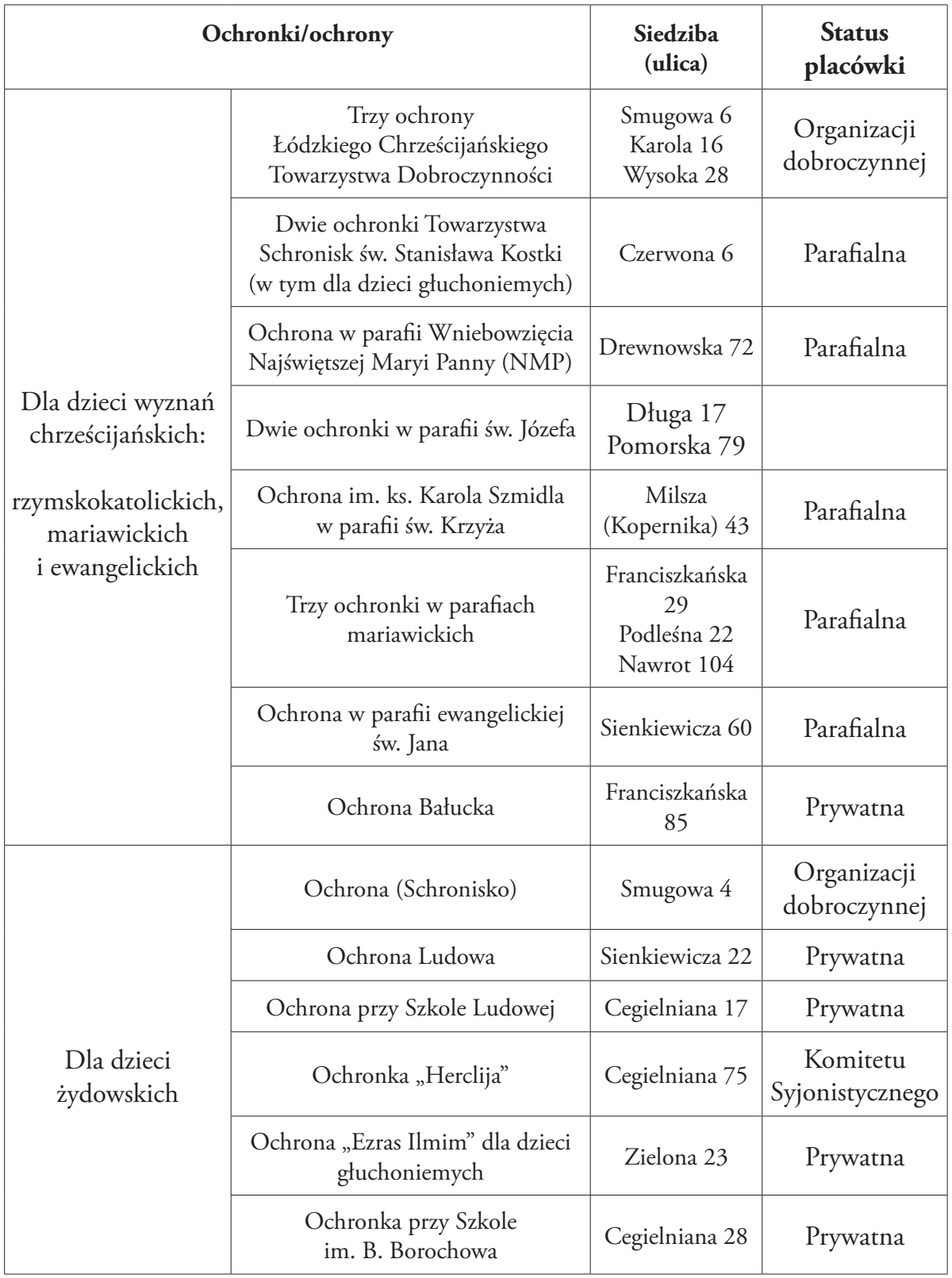

Źródło: APE, AmE, WOS, 1922-1923: k. 23-24. 
Warto zauważyć, że w kwietniu 1920 r. pojawił się w lokalnej przestrzeni publicystycznej - i to z ramienia samorządu - tekst dotyczący problematyki wychowania przedszkolnego. Na łamach „Dziennika Zarządu Miasta Łodzi”, organu prasowego władz miejskich, opublikowano obszerny artykuł napisany przez warszawskiego lekarza - Jana Szmurło, w którym kreślił on historyczny aspekt powstania ochronek, przedstawiając również funkcjonowanie tego typu instytucji na terenie Warszawy (warszawski Wydział Szkolny posiadał w tamtym okresie 53 ochrony ze 136 oddziałami i taką samą liczbą ochroniarek) (Szmurło 1920a: 7-12; Szmurło 1920b: 5-11). Autor zwracał uwagę na konieczność zapewnienia dzieciom zdrowych i higienicznych warunków zabawy, poruszał problematykę kształcenia personelu w zakresie teorii i praktyki pedagogicznej oraz kwestię właściwego kierunku programowo-wychowawczego tych instytucji. Szczególne zadania lekarz wyznaczał władzom miejskim, pisząc następująco: „Rola miasta powinna polegać na budowaniu ochron, odpowiadających wymaganiom hygjeny i dostarczaniu niezbędnych środków na zaopatrzenie ich w bieliznę, mydło i żywność w odpowiedniej ilości i gatunku" (Szmurło 1920b: 8-9) ${ }^{12}$. Przekonywał, że zadaniem lokalnych włodarzy powinno być również popieranie społecznych inicjatyw w zakresie stosowania nowych metod wychowania sprzyjających rozwojowi dziecka, tak pod względem fizycznym, jak moralnym.

Ważnym przedsięwzięciem, świadczącym o zmianie kierunku myślenia o wychowaniu dziecka w wieku przedszkolnym, było w Łodzi przekazanie - przez władze miejskie - spraw dotyczących ochronek z Wydziału Dobroczynności Publicznej do powstałego w marcu 1921 r. Wydziału Oświaty i Kultury Zarządu m. Łodzi (wcześniej był to Wydział Szkolnictwa). Tę drugą jednostkę podzielono wtedy na trzy referaty: Oddział Szkolnictwa, Oddział Obowiązku Szkolnego oraz Oddział Kultury i Oświaty Pozaszkolnej. Sprawy łódzkich przedszkoli leżały w gestii Oddziału Szkolnictwa (Sosnowska 2013). Do radykalnego posunięcia w polityce oświatowej łódzkich władz szkolnych doszło w początkach roku 1922, kiedy do Stefana Kopcińskiego, przewodniczącego miejskiego Wydziału Oświaty i Kultury (WoiK), najpierw drogą nieoficjalną, a następnie urzędową dotarły negatywne opinie o działalności ochronek społecznych w mieście. Dysponentem informacji był Departament Szkolnictwa Powszechnego Ministerstwa Wyznań Religijnych i Oświecenia Publicznego, który przysłał pismo datowane na 2 lutego 1922 r. następującej treści: „Ministerstwo [WriOP] przesyła $\mathrm{w}$ załączeniu sprawozdanie $\mathrm{z}$ wizytacji ochronek $\mathrm{m}$. Łodzi do wiadomości, oraz celem zużytkowania przy dalszej organizacji ochronek i wykonywaniu nad niemi nadzoru" (APŁ, AmE, WOiK, 1922-1925: k. 5; Pismo Departamentu 1922). Ponieważ, jak przeczytamy dalej, ,załącznik” zawierał niezbyt pochlebną opinię o działalności

12 W cytowanych tekstach zachowano oryginalną pisownię - nie zaznaczano błędów ortograficznych ani nie dokonywano zmian w interpunkcji. 
łódzkich placówek, wprawdzie nie prowadzonych przez samorząd, ale funkcjonujących na jego terenie, podjęto kroki zmierzające do naprawy sytuacji.

Wcześniej jeszcze, z polecenia Referatu Wychowania Przedszkolnego przy Ministerstwie WriOP, do Łodzi przybyła Maria Wernikówna, która na przełomie listopada i grudnia 1921 r. (28 XI-18 XII) wizytowała ochronki oraz zakłady wychowawcze zamknięte (schroniska) funkcjonujące w mieście (APŁ, AmE, WOiK, 1922-1925: k. 7-12; Sprawozdanie z wizytacji ochronek m. Eodzi 1921)13. Odwiedziła ogółem 43 placówki, w tym 17 zakładów mających status ochron/ochronek „dla dzieci przychodnich". W sprawozdaniu pokontrolnym - na które powoływał się wspomniany Departament Szkolnictwa Powszechnego - M. Wernikówna przekazywała władzom oświatowym w Warszawie informacje na temat stanu tódzkich placówek dla dzieci w wieku przedszkolnym. Nie były to wiadomości pozytywne, bowiem stwierdziła ona, że „wszystkie ochronki znajdują się w opłakanych warunkach materialnych, co rzeczywiście fatalnie się odbija na prowadzeniu tychże" (Sprawozdanie z wizytacji ochronek m. Łodzi 1921). Z powodu braku środków finansowych zarządy, jako organy prowadzące ochronki, „dają wychowawczyniom niebywale niskie uposażenie”, co z kolei powodowało, iż zatrudniano osoby bez kwalifikacji. Kolejnym mankamentem w pracy ochronek społecznych był z jednej strony niedostatek pomocy dydaktycznych niezbędnych do prowadzenia zajęć, z drugiej - ograniczanie metod pracy z dziećmi do pogadanek i zabaw, „prowadzonych bez zrozumienia”. Niski poziom cechował również działalność tych instytucji pod względem wychowawczym. Jako „najlepiej prowadzone jeszcze i najbardziej odpowiadające swemu przeznaczeniu” wizytująca wyróżniła kilka placówek: trzy ochronki należące do parafii mariawickich, jedną z ochronek parafialnych Towarzystwa Schronisk św. Stanisława Kostki, jedną (polsko-niemiecka) ochronkę należącą do Łódzkiego Chrześcijańskiego Towarzystwa Dobroczynności, dwie ochronki parafii rzymskokatolickich: św. Józefa i Wniebowzięcia NMP oraz jedną z ochronek żydowskich (ochronkę „Herclija” z ul. Cegielnianej 75), „gdzie dzieci są doskonale żywione”, a sama placówka „robi wrażenie zamożnej”.

M. Wernikówna nie ograniczyła się wyłącznie do stwierdzenia stanu funkcjonowania łódzkich ochronek, ale o „brakach pedagogicznych” poinformowała tak wychowawczynie, jak i zarządy wszystkich hospitowanych placówek. Ponieważ jednak brak środków finansowych w kasie organizacji społecznych na doposażenie ochronek i zatrudnienie odpowiedniej kadry nie rokował pomyślnie, a nawet wiązał się z koniecznością likwidacji tych placówek, zwróciła się ona o pomoc w prowadzeniu społecznych instytucji dla dzieci przedszkolnych do władz miasta Łodzi. Komunikat na temat „rozpaczliwych warunków, w jakich znajdują się ochronki łódzkie”

13 M. Wernikówna zaznaczyła, że szczegółowe uwagi o każdej ochronce zamieściła w oddzielnych sprawozdaniach, przekazanych MWRiOP. 
M. Wernikówna przedstawiła podczas spotkania z przewodniczącym miejskiego Wydziału Oświaty i Kultury - S. Kopcińskim (zanim sprawozdanie powizytacyjne przekazała do centralnych władz szkolnych w Warszawie). Zgłosiła wówczas trzy propozycje, po pierwsze - przejęcie przez Magistrat m. Łodzi wydatków personalnych ochronek w formie finansowania wynagrodzeń wychowawczyń, po drugie - przejęcie wydatków potrzebnych na wyposażenie placówek w pomoce dydaktyczne, i po trzecie - finansowanie stanowiska referentki ds. wychowania przedszkolnego w Łodzi (wizytatorki ochronek) zaproponowanej przez Wydział Wychowania Przedszkolnego przy MWRiOP (do czasu utworzenia takiego stanowiska przy Kuratorium Okręgu Szkolnego Łódzkiego) (Sprawozdanie z wizytacji ochronek m. Łodzi 1921). Ponieważ sprawa ta dotyczyła ochronek, czyli instytucji podległych wtedy miejskiemu Wydziałowi Opieki Społecznej, S. Kopciński zmuszony był porozumieć się z Dorotą Kłuszyńską (przewodniczącą WOS). Na kolejnym posiedzeniu (12 XII 1921 r.), w obecności również Inspektora Szkolnego m. Łodzi, M. Wernikówna otrzymała zapewnienie, że łódzki Magistrat wyraził zgodę na zaproponowane przez nią wnioski. Jedyny warunek, jaki wówczas postawiono, to prawo ingerencji władz miasta w sprawy natury pedagogicznej i personalnej odnośnych placówek. O ustaleniach na linii: MWRiOP - łódzkie władze miejskie (WoiK) - lokalne władze oświatowe (Inspektor Szkolny m. Łodzi) poinformowano zarządy organizacji dobroczynnych i pozostałych instytucji społecznych prowadzących ochronki podczas wspólnego posiedzenia 15 grudnia $1921 \mathrm{r}$. Nie wszyscy obecni wówczas przedstawiciele zarządów wyrazili aprobatę dla tych ustaleń, ale większa liczba obecnych zaakceptowała powzięte postanowienia. Dotyczyły one ponadto zagwarantowania dzieciom, przez zarządy ochronek, opieki lekarskiej w prowadzonych placówkach oraz zgody na przekazywanie Inspektorowi Szkolnemu m. Łodzi sprawozdań z działalności tych ochronek, które otrzymywałyby wsparcie finansowe z kasy miejskiej.

\section{Wychowanie przedszkolne w Łodzi w latach 1922-1924}

Z początkiem stycznia 1922 r. przedstawiciele łódzkich władz miejskich podjęli oficjalną decyzję, że wszelkie sprawy dotyczące funkcjonowania łódzkich ochronek społecznych pod względem pełnienia przez nie funkcji pedagogicznych znajdą się w gestii miejskiego Wydziału Oświaty i Kultury (w Oddziale Szkolnictwa). Ten z ramienia Zarządu m. Łodzi będzie zatrudniać i wynagradzać ochroniarki oraz wizytatorki ds. wychowania przedszkolnego, a także wyposażać placówki w niezbędne pomoce naukowe (Sprawozdanie z wizytacji ochronek m. Łodzi 1921: k. 1; Wyciag z posiedzenia Wydziatu Szkolnictwa Magistratu m. Eodzi 1922, uchwała nr 1; k. 2. Wyciag z posiedzenia Magistratu m. Eodzi 1922, uchwała nr 14). Stosowną uchwałę Rada Miejska 
podjęła 8 lutego (Sprawozdanie z wizytacji ochronek m. Eodzi 1921: k. 4 Wyciag z protokotu posiedzenia Rady Miejskiej m. Łodzi 1922). Treść dokumentu, który administracja miejska wkrótce przekazała zarządom organizacji, parafii i osobom prywatnym jako właścicielom ochronek, brzmiała następująco:

1) Zarząd ochrony wyraża zgodę na powierzenie kierunku wychowawczego Wydziałowi Oświaty i Kultury; Wydział sprawuje nadzór nad ochroną przez swoich wizytatorów. 2) Personel wychowawczy przyjmuje i zwalnia Wydział Oświaty i Kultury w porozumieniu z Zarządem ochrony, względnie na warunkach tegoż Zarządu. 3) Wydział Oświaty i Kultury zaopatruje ochrony w pomoce naukowe; pomoce te zostają własnością miasta. 4) Zatrudniony obecnie personel w ochronach pozostaje na stanowisku do dnia 1 lipca 1922 r.; dalsze pozostawienie uzależnia się od posiadania odpowiednich kwalifikacji przez wychowawczynie ochron, decyzję w tej mierze zastrzega sobie Wydział Oświaty i Kultury. Za nieodpowiednie zachowanie się personel wychowawczy może być zwolniony w każdej chwili. 5) Wydział Oświaty i Kultury przejmuje kierunek wychowawczy w tych ochronach, które w chwili obecnej odpowiadają warunkom higienicznym i czynią zadość wymaganiom pod innemi względami wychowawczymi (Sprawozdanie z wizytacji ochronek m. Eodzi 1921: k. 14) ${ }^{14}$.

W ciągu kolejnych kilku miesięcy 1922 r. trwała wymiana korespondencji między WoiK a reprezentantami zarządów. Jak nadmieniono, nie wszyscy właściciele ochronek społecznych, obawiając się zbytniej ingerencji władz miejskich w działalność ich instytucji, wyrazili zgodę na tak postawione warunki. Jednym z nich był ks. Bronisław Siennicki, proboszcz parafii rzymskokatolickiej pw. św. Józefa, który sprzeciwiając się objęciu przez WoiK kierunku wychowawczego w ochronkach tej parafii, zrzekł się pomocy finansowej i materialnej. Tak uzasadniał swoje stanowisko:

Zarząd ochrony [jest] w głębokim przekonaniu, że dotychczasowy sposób prowadzenia ochronki jest jedynym, który pozwala wzrastać dziatwie w atmosferze czystej, uczciwej, spokojnej, zważywszy i nadto, że powierzanie dziatwy ochrony eksperymentom Wydziału byłoby zdradą zaufania rodziców, którzy dla kierunku panującego w ochronie, powierzają jej swe dzieci (Sprawozdanie z wizytacji ochronek m. Łodzi 1921: k. 35-36).

Zarządy innych parafii zaakceptowały postawione warunki. Ustalenia badawcze pozwalają na stwierdzenie, że od grudnia 1922 do maja 1923 r. stosowną umowę podpisało 15 placówek dla dzieci w wieku przedszkolnym (Sprawozdanie z wizytacji ochronek m. Łodzi 1921: 396-397): dziewięć ochronek istniejących już od 1918 r. $^{15}$ oraz

\footnotetext{
14 Warunki, na jakich może nastąpić przejęcie przez Wydział Oświaty i Kultury, w myśl uchwały Rady Miejskiej z dnia 8 lutego r.b. [1922] poszczególnych ochron pod względem wychowawczym.

15 Ochrona ŁChTD przy ul. Smugowej 6, Ochronki Towarzystwa Schronisk św. Stanisława Kostki, Ochrona im. ks. K. Szmidla w parafii św. Krzyża, ochronki w parafiach mariawickich, Ochrona Bałucka, żydowska ochrona przy ul. Smugowej 4.
} 
sześć nowo powołanych w mieście społecznych placówek przedszkolnych ${ }^{16} . \mathrm{Z}$ czasem pod kierownictwo WoiK przechodziły kolejne instytucje, inne rezygnowały, jeszcze inne były poddawane likwidacji przez organy prowadzące (na przełomie 1930/1931 r. WoiK dotował 14 takich instytucji, ale miasto posiadało już 11 własnych przedszkoli; Sosnowska 2017: 296-297, tabela 3).

Wraz z rokiem szkolnym 1923/1924 - nowo wybrani, dzięki kolejnym wyborom samorządowym (w maju 1923 r.), przedstawiciele WoiK postanowili przeprowadzić wizytację ochronek społecznych subwencjonowanych, a więc kierowanych przez miasto. W dniach 4-8 października 1923 r. osobiście zwiedzali placówki, aby przekonać się o prowadzonej działalności. Spostrzeżenia pokontrolne zawarte w sprawozdaniu przekazanym współpracownikom podczas posiedzenia WoiK świadczyły o niespełnianiu najbardziej elementarnych warunków opieki i wychowania dziecka. W przypadku nowo powstałej Ochrony Stowarzyszenia Spożywców „Nasze Wyzwolenie” przy ul. Sienkiewicza 22 odnotowano:

Lokal, gdzie ma się mieścić ochrona znajduje się na III piętrze w oficynie. Ochrony jednak nie ma; jest oddział szkolny, który stanowi część szkoły przy ul. Cegielnianej nr 17, utrzymywanej przez to samo towarzystwo [stowarzyszenie]. W lokalu zastano nauczycielkę Esterę Chardak. Dzieci zapisanych 40, obecnych - 16. Mebli, urządzeń szkolnych, pomocy naukowych nie ma wcale. Jest kilka krzesełek, prawdopodobnie z ochrony oraz kilka stolików. Gdzie jest ochrona, nauczycielka nie wie (APŁ, AmŁ, WOiK 1922-1925: k. 400).

O jednej z ochron Robotniczego Wydziału Wychowania Dziecka i Opieki nad Nim - instytucji powstałej w Łodzi w maju 1923 r. pod patronatem Oddziału Łódzkiego Polskiej Partii Socjalistycznej, napisano:

Lokal na I piętrze składa się z jednej maleńkiej, zniszczonej salki, zastawionej ławkami; miejsca do zabaw nie ma wcale. $Z$ liczby zapisanych 25 dzieci obecnych jest 13; są to dzieci w wieku szkolnym, uczęszczające w porze popołudniowej do szkół; tutaj odrabiają lekcje. Przebywają w lokalu od 9 do 12.00. Nauczycielka p. Machalska [Zofia] prowadząca komplet, oświadcza, że w porze popołudniowej prowadzi w godz. 14-17 inny komplet przy ul. Wólczańskiej 196. Wedle jej oświadczenia, lokal tam jest jeszcze gorszy; zapisanych w nim jest 50 dzieci, które znów w rannej porze uczęszczają na naukę do szkół (APŁ, AmŁ, WOiK, 1922-1925: k. 404).

\footnotetext{
16 Nowo powstałe placówki to: Ochrona Towarzystwa Spółdzielczego „Młot” im. J. Szurka przy ul. Piramowicza 14, Ochrony Stowarzyszenia Spożywców „Nasze Wyzwolenie” przy ul. Łagiewnickiej 25 i Sienkiewicza 22, Ochrony Robotniczego Wydziału Wychowania Dziecka i Opieki nad Nim (przy ul. Piotrkowskiej 53, Wólczańskiej 196, Aleksandrowskiej 39).
} 
Można zatem wnioskować, że pomimo umowy podpisanej z władzami miejskimi zarządy ochronek wspieranych finansowo nie przestrzegały jej postanowień. Nie skłaniając się ku akceptacji przedstawionego wyżej stanu funkcjonowania ochronek społecznych, warto zaznaczyć, że podobne sytuacje, gdy w ochronach przebywały dzieci szkolne, odnotowywano w skali całego kraju. Informowała o tym Z. Zukiewiczowa podsumowująca 15-lecie pracy przedszkoli w Polsce, mówiąc:

Statystyka za rok 1919/20 przeprowadzona przez Ministerstwo W. R. i O. P., wykazała, iż tylko 60,8\% tych zakładów wychowuje dzieci wyłącznie w wieku przedszkolnym i może być zarejestrowana, jako instytucje wychowania przedszkolnego. Pozostałe gromadziły dzieci do lat 14-15, ucząc je pacierza, czytania, pisania, początkowych rachunków i robót ręcznych. Jeśli wśród wychowanków były dzieci w wieku przedszkolnym, stanowiły one „dodatek”, któremu poświęcano mniej uwagi (...) (Żukiewiczowa 1933/34: 38).

Zatem, w celu „podniesienia sprawy wychowania przedszkolnego w istniejących ochronach”, nowe władze WoiK uznały za niezbędne: „zorganizowanie fachowej wizytacji oraz periodycznej kontroli ochron; ustalenie minimalnych potrzeb [instytucji]; zaopatrywanie w pomoce naukowe; zaopatrywanie w żywność; zapewnienie opieki lekarskiej" oraz podjęły stosowną uchwałę (APE, AmE, WOiK 1922-1925: k. 399). Istotny z punktu dalszego rozwoju wychowania przedszkolnego w Łodzi był następujący zapis: „jednocześnie uznano za wskazane otwieranie miejskich ochron-przedszkoli w miarę otrzymywania do dyspozycji odpowiednich lokali” (APE, AmE, WOiK 1922-1925: k. 399). Niedostatek pomieszczeń był wtedy jedną z przyczyn braku inicjatywy ukierunkowanej na organizowanie własnych, miejskich placówek przedszkolnych. Tymczasem ponowną wizytację ochronek społecznych zlecono odpłatnie Marii Łabęckiej, dyrektorce Państwowego Seminarium Ochroniarskiego w Łodzi (potem w Opatówku, niedaleko Kalisza). W połowie października 1923 r. otrzymała ona upoważnienie do kontroli 15 placówek. W świetle dokonanego przeglądu okazało się, że stan tylko nielicznych z nich nie budził zastrzeżeń, w większości pomieszczeń nadal brakowało pomocy dydaktycznych, warunki higieniczne były bardzo złe, a lokale nadawały się do remontu. Największe zastrzeżenia zgłaszała wizytująca do kwalifikacji wychowawczyń, toteż, oprócz systematycznych kontroli, na początku 1924 r. zorganizowała konferencję metodyczną, wspartą pokazem pomocy dydaktycznych, w której uczestniczyły ochroniarki i miejskie władze szkolne (Ochrony-przedszkola, DZMŁ 1924: 12). WoiK wystosował również do zarządów ochronek pismo zachęcające wychowawczynie do zwiedzenia w Warszawie wystawy dotyczącej wychowania przedszkolnego. W podsumowaniu półrocznej pracy (sierpień 1923 - luty 1924) władze WoiK tak oceniały swój wysiłek: „działalność Oddziału Szkolnictwa zmierzała do ujednostajnienia metod wychowania w przejętych pod względem wychowawczym 
ochronach, (...) pragnęliśmy zainteresować personel wychowawczy ochron, (...) najnowszemi metodami stosowanemi na tym poziomie wychowania" (Wydziat Ośw. [Oświaty] i Kultury, DZMŁ1924: 32 i 33).

Miasto nadzorowało w tym czasie 17 placówek przedszkolnych (14 dla dzieci wyznań chrześcijańskich i 3 dla dzieci żydowskich) oraz refundowało wynagrodzenia łącznie 31 ochroniarkom (odpowiednio: 24 i 7). Z własnych budynków korzystało sześć ochron, pozostałe mieściły się w lokalach dzierżawionych, najczęściej nieodpowiednich pod względem warunków higieniczno-sanitarnych oraz słabo wyposażonych w pomoce dydaktyczne. W nieodległych projektach miejskich władz oświatowych znalazła się kwestia zapewnienia stałej opieki lekarskiej nad dziećmi, zakupu potrzebnych sprzętów i akcesoriów naukowych, a przede wszystkim „zorganizowania szeregu wzorowych ochron-przedszkoli, planowo w mieście rozmieszczonych" (Wydziat Ośw. [Oświaty] i Kultury, DZMŁ 1924: 33). Inicjatorom przedsięwzięcia zależało na uruchomieniu placówek w różnych częściach miasta, ale przede wszystkim na obrzeżach. Peryferie zasiedlała uboga ludność robotnicza, głównie narodowości polskiej, i to właśnie dzieciom z tych rodzin starano się zapewnić opiekę przedszkolną.

Do istotnego, z punktu widzenia rozwoju łódzkiej edukacji przedszkolnej, wydarzenia, jakim było powołanie miejskiej placówki przedszkolnej, doszło już wkrótce, bowiem pierwszą własną placówkę Zarząd m. Łodzi uruchomił 1 marca 1924 r. Lokum I Miejskiej Ochrony-Przedszkola stanowiły wyremontowane pomieszczenia kamienicy przy ul. Radwańskiej 42 (Oddziat Szkolnictwa, DZMŁ 1924: 8) ${ }^{17}$. Instytucję wyposażono w meble: 8 stolików, 48 krzesełek i stół nauczycielski (APŁ, AmE, WOiK 1924-1926: k. 82). Zapisy do nowo powstałej ochronki wyznaczono w ostatnim tygodniu lutego, ale jak się okazało - napływ dzieci był niewielki. Instytucję uruchomiono w dość zamożnej dzielnicy Łodzi, którą stanowiła w większości ludność pochodzenia niemieckiego. Według Janiny Pawłowskiej, późniejszej inspektorki wychowania przedszkolnego w Łodzi, wśród rodziców dzieci w wieku przedszkolnym utrzymywał się raczej nieufny stosunek do ochronek miejkkich w pierwszych latach ich funkcjonowania (Pawłowska 1935: 616). WoiK wystosował więc prośbę do kierownictwa Miejskiej Szkoły Powszechnej nr 44 z ul. Radwańskiej 69, aby wśród rodziców rozpropagowano informację o otwarciu instytucji. Akcja się powiodła i do placówki przyjęto początkowo 32 dzieci w wieku 4-6 lat; funkcjonował jeden oddział przedszkolny. Jako pierwszą na etacie wychowawczyni zatrudniono Eugenię Włodarkówną, absolwentkę Państwowego Seminarium dla Ochroniarek, której jeszcze przed otwarciem placówki powierzono pełnienie obowiązków kierowniczki ochrony (APŁ, AmE, WOiK 19241926: k. 116). Z nowym rokiem szkolnym 1924/1925 otwarto drugą grupę dziecięcą, angażując Marię Wiśniewską.

W 1929 r. zmieniono jej lokal na ul. Radwańską 54. 
Jeszcze w tym samym 1924 r. władze Łodzi powołały do życia dwie kolejne ochronki przy ulicach: Wacława 2/4 i Kilińskiego 100 (potem ul. Przejazd 39) (APŁ, AmE, WOiK 1924-1926: k. 102, 105, 107; II Miejska Ochrona-Przedszkole 1924-1926: k. 20). Wspólna uroczystość poświęcenia trzech miejskich instytucji wychowania przedszkolnego odbyła się 22 listopada przy udziale delegatów duchowieństwa, włodarzy miasta oraz przedstawicieli Kuratorium Okręgu Szkolnego Łódzkiego. Ówczesny prezydent Łodzi Marian Cynarski „wyjaśnił dziatwie i zebranym rodzicom znaczenie ochron przedszkoli, jak również podkreślił, iż Magistrat (...) będzie nadal dążył do tego, aby ochron takich w naszem mieście robotniczem było jak najwięcej” (Poświęcenie miejskich ochron-przedszkoli 1924: 14). Po przemówieniach odbyły się „lekcje poglądowe”, zabawy i gry dla dzieci. W trzech ochronkach-przedszkolach znalazło wtedy miejsce ponad 200 dzieci w wieku 4-7 lat.

Warto nadmienić, że dobra passa związana z możliwościami tworzenia przedszkoli pod kierownictwem miejskich władz szkolnych trwała nadal - w roku następnym (1925) otwarto kolejne dwie ochrony-przedszkola (APE, AmE, WOiK 1927-1930). W latach 1926/1927 do pięciu miejskich ochronek-przedszkoli (11 oddziałów) uczęszczało 376 dzieci (183 dziewczynki i 193 chłopców), ale zdecydowanie więcej dzieci przebywało w dotowanych przez miasto przedszkolach społecznych.

Należy pokrótce wspomnieć, że dalszy rozwój i przeobrażenia, jakie nastąpiły w wychowaniu przedszkolnym w Łodzi w okresie 1926-1939, wiążą się, oprócz organizowania nowych placówek, z innymi zagadnieniami. Po pierwsze: w łódzkim samorządzie, w Wydziale Oświaty i Kultury zatrudniono inspektorkę Janinę Pawłowską, która otrzymała stanowisko kierowniczki miejskiego Referatu Wychowania Przedszkolnego i będąc propagatorką nowych koncepcji wychowawczych (głównie M. Montessori i O. Decroly'ego), dbała o konsekwentne wprowadzanie tych założeń do pracy pedagogicznej łódzkich przedszkoli, miejskich i społecznych (Sosnowska 2016) ${ }^{18}$. Po drugie: w mieście wielonarodowym i wielowyznaniowym, gdzie istniały przedszkola dla dzieci różnych konfesji, samorząd starał się integrować środowiska i podmioty prowadzące własne placówki na rzecz tworzenia wychowankom właściwych warunków materialnych i opiekuńczo-wychowawczych (przykładem mogą być wspólne konferencje, kursy i warsztaty metodyczne, wycieczki do Liskowa i Warszawy czy uroczystości przedszkolne) (Sosnowska 2017). Po trzecie: skutki ogólnoświatowego kryzysu gospodarczego - trwającego w Łodzi w latach 1930-1935 - i wiążące się z nim niedogodności życia, jak zamykanie fabryk i zakładów produkcyjnych, bezrobocie, pauperyzacja, głód, choroby, eksmisje i patologie społeczne, spowodowały przesunięcie priorytetów w dziedzinie oświaty (Sosnowska 2018: 36-58); placówki

18 W ciągu pierwszego roku pracy w WOiK J. Pawłowska odbyła 161 wizytacji, 11 zebrań z opieką rodzicielską w przedszkolach oraz 7 konferencji z personelem wychowawczym wszystkich łódzkich przedszkoli. 
przedszkolne, realizując państwowe i samorządowe programy pomocowe, stały się wtedy miejscem regularnego dożywiania dzieci, gwarantując wychowankom opiekę socjalną, ale - co warto podkreślić - nie rezygnowano wówczas z wdrażania do praktyki edukacyjnej nowych koncepcji wychowawczych. Po czwarte: wraz z wprowadzeniem ustawy o ustroju szkolnictwa z 11 marca 1932 r. uregulowano kwestie wymagań kwalifikacyjnych i zawodowych wychowawczyń, chociaż w Łodzi znacznie wcześniej powzięto decyzję, aby osoba ubiegająca się o stanowisko wychowawczyni przedszkola posiadała świadectwo siedmioklasowej szkoły powszechnej i seminarium ochroniarskiego na prawach państwowych oraz „pewną praktykę” (APŁ, AmE, WOiK, sygn. 1927-1930: k. 6).

\section{Konkluzja}

W centrum spraw społeczno-oświatowych podnoszonych przez łódzki samorząd pierwszej kadencji kwestia opieki nad dziećmi w wieku przedszkolnym znalazła się dopiero w roku 1921, gdy nadzór nad działalnością ochronek społecznych - jedynych funkcjonujących w mieście - objął Wydział Oświaty i Kultury Zarządu m. Łodzi. To wydarzenie można uznać za początek przeobrażeń w dziedzinie wychowania przedszkolnego, dotąd bowiem sprawy instytucji przedszkolnych znajdowały się w gestii Wydziału Dobroczynności Społecznej, jednostki administracji miejskiej kojarzonej, podobnie zresztą jak w przypadku ochronek społecznych, z działalnością filantropijną. Kolejnym krokiem przybliżającym korzystne zmiany w polityce oświatowej łódzkich władz szkolnych były niezbyt pochlebne wyniki kontroli przeprowadzonej na terenie Łodzi przez delegatkę Referatu Wychowania Przedszkolnego przy Ministerstwie WriOP. Ujawniono wówczas spore zaniedbania w funkcjonowaniu ochronek społecznych. W rezultacie w początkach 1922 r. władze miejskie podjęły decyzję o roztoczeniu nadzoru pedagogicznego nad tymi placówkami oraz o wypłacie dotacji finansowych na wynagrodzenia wychowawczyń. Następne wizytacje, dokonane tym razem przez nowo wybranych przedstawicieli Wydziału Oświaty i Kultury oraz przez dyrektorkę Państwowego Seminarium Ochroniarskiego w Łodzi, ponownie ujawniły rażące usterki w pracy instytucji przedszkolnych. Niekorzystny stan wychowania przedszkolnego w mieście stał się w 1924 r. bezpośrednim impulsem do zorganizowania przez samorząd pierwszego i kilku następnych własnych ochron-przedszkoli. Tą inicjatywą próbowano, i - jak wykazują badania - nadano nowy kierunek pedagogiczny wychowaniu przedszkolnemu w mieście.

Warto nadmienić, że w okresie dwudziestolecia międzywojennego zmienił się status placówek przeznaczonych dla dzieci w wieku 3-7 lat. Bezpośrednio po I wojnie światowej traktowano je głównie jako miejsca opieki nad dzieckiem i pomocy 
materialnej świadczonej rodzinie. W kolejnych latach znaczenie przedszkola uległo zasadniczej zmianie - stało się miejscem wychowania i aktywności edukacyjnej podopiecznych. Nie zmieniło to jednak faktu, że np. w Łodzi liczącej ponad pół miliona mieszkańców (w tym 30 tys. dzieci w wieku przedszkolnym) tylko garstka (w 1926 r. 1500 wychowanków) mogła korzystać z instytucjonalnego wychowania przedszkolnego. Po upływie dziesięciolecia (1924-1934) Łódź posiadała 59 przedszkoli, w tym 13 miejskich, do których uczęszczało tylko 825 dzieci, natomiast do 28 przedszkoli społecznych - 1753 wychowanków, do 18 przedszkoli prywatnych - 330. Z liczby 33680 łódzkich dzieci w wieku przedszkolnym zaledwie 2908 (8,6\%) uczęszczało do przedszkoli (Z życia miast. Przedszkola miejskie, DZMŁ 1933: 958).

\section{Bibliografia}

\section{I. Źródła archiwalne}

Archiwum Państwowe w Łodzi, Akta miasta Łodzi

Wydział Oświaty i Kultury:

sygn. 16789: I Miejska Ochrona-Przedszkole 1924-1926

sygn. 16791: II Miejska Ochrona-Przedszkole 1924-1926

sygn. 16802: Sprawozdania kwartalne przedszkoli miejskich 1929-1933

sygn.16803: Ochrony subsydiowane przez Zarząd Miejski w Łodzi 1925-1926

sygn. 16804: Ochrona społeczna subsydiowana przez Zarząd Miejski w Łodzi 1922-1925

sygn. 16807: Wychowanie przedszkolne (sprawy ogólne przedszkoli miejskich) 1927-1930 sygn. 16837: Opieka nad dziatwą 1917-1921

\section{Wydział Opieki Społecznej}

sygn. 570: Instytucje dobroczynne 1922-1923

sygn. 18519: Sprawozdania Łódzkiej Miejscowej Rady Opiekuńczej 1917.

\section{Pozostałe pozycje}

Bobrowska-Nowak W. (1978). Historia wychowania przedszkolnego, Warszawa: WSiP.

Goerne A. (1919). Z zakresu statystyki szkolnej, [w:] Informator m. Eodzi z kalendarzem na rok 1919, Łódź: [brak wydawcy].

Jamrożek W. (2009). Trzy kongresy pedagogiczne, „Biuletyn Historii Wychowania”, nr 25. Księga pamiątkowa dziesięciolecia samorządu miasta Łodzi 1919-1929 (1930), Łódź: [brak wydawcy].

Mauersberg S. (1980). Sejm Nauczycielski (14-17 kwietnia 1919 r.), „Rozprawy z Dziejów Oświaty”, t. XXIII.

Miąso J. (red.) (1980). Historia wychowania: wiek XX, t. 1, Warszawa: PWN. 
Nartonowicz-Kot M. (1985). Samorząd tódzki wobec problemów kultury w latach 19191939, „Acta Universitatis Lodzensis, Folia Historica”, nr 21.

Ochrony-przedszkola (1924). „Dziennik Zarządu Miasta Łodzi”, nr 5.

Oddziat Szkolnictwa (1924). „Dziennik Zarządu Miasta Łodzi”, nr 32.

O szkotę polską. Pierwszy ogólnopolski wielki Zjazd nauczycielski w dniach 14, 15, 16, 17 kwietnia MCMXIX w Warszawie (1920). Lwów-Warszawa: Książnica Polska Towarzystwa Nauczycieli Szkół Wyższych.

Pawłowska J. (1935). Opieka nad dzieckiem w wieku przedszkolnym na terenie miasta Łodzi, „Dziennik Zarządu Miasta Łodzi”, nr 10.

Poświęcenie miejskich ochron-przedszkoli (1924). „Dziennik Zarządu Miasta Łodzi”, nr 49.

Rzepkowski A. (2008). Ludność miasta Łodzi w latach 1918-1939, Łódź: Wydawnictwo Ibidem.

Stowo wstęne (1925). „Wychowanie Przedszkolne”, nr 1.

Smolik P. (1929). Dziesięć lat dziatalności oświatowej i kulturalnej Samorządu Eódzkiego, Łódź: [brak wydawcy].

Sosnowska J. (2013). Wydziat Oświaty i Kultury Zarządu miasta Łodzi w upowszechnianiu edukacji dziecka w dwudziestoleciu międzywojennym, „Kultura i Wychowanie”, nr 5.

Sosnowska J. (2014). Instytucje wychowania przedszkolnego w wielokulturowej Łodzi w latach 1924-1939. Organizacja, zadania, formy dziatania, „Wychowanie w Rodzinie”, t. IX.

Sosnowska J. (2016). Janina Pawtowska (1895-1972) i jej koncepcja wychowania oraz opieki nad dziećmi w międzywojennej Łodzi, [w:] U. Kozłowska, T. Sikorski, A. Wątor (red.), Obywatelki na obcasach. Kobiety w życiu publicznym (XIX-XXI w.), t. I, Radzymin-Warszawa: Wydawnictwo von Borowiecky.

Sosnowska J. (2018). Z dziejów opieki spotecznej w Polsce międzywojennej. Pótkolonie letnie $w$ Łodzi, Łódź: Wydawnictwo Uniwersytetu Łódzkiego.

Szczepańska B. (2002). Dziatalność tódzkiego samorządu miejskiego w dziedzinie oświaty powszechnej i pozaszkolnej w latach 1919-1939, Łódź: Wydawnictwo Uniwersytetu Łódzkiego.

Szmurło J. (1920a). Ochrony miejskie a hygiena. Cz. I, „Dziennik Zarządu Miasta Łodzi”, nr 16.

Szmurło J. (1920b). Ochrony miejskie a hygiena. Cz. II, „Dziennik Zarządu Miasta Łodzi”, nr 17.

Wasiak J. (1980). Ksztattowanie się samorzadu miejskiego w Polsce centralnej w latach 19151926, „Acta Universitatis Lodziensis, Folia Historica”, nr 1.

Wróbel M. (1967). Wychowanie przedszkolne w Polsce w latach 1918-1939, Wrocław-Warszawa-Kraków: Zakład Narodowy im. Ossolińskich, Wydawnictwo PAN,

Wydziat Ośw. [Oświaty] i Kultury (1924). „Dziennik Zarządu Miasta Łodzi”, nr 20.

Z życia miast. Przedszkola miejskie (1933). „Dziennik Zarządu Miasta Łodzi”, nr 45.

Żukiewiczowa Z. (1933/34). Piętnastolecie wychowania przedszkolnego w Niepodlegtej Polsce, „Przedszkole” nr 3.

Żukiewiczowa Z. (1934/35). Dziesięciolecie Przedszkoli Miejskich m. Łodzi, „Przedszkole”, nr 2. 


\section{ADRES DO KORESPONDENCJI}

dr hab. Joanna Sosnowska

Uniwersytet Łódzki

Wydział Nauk o Wychowaniu

Katedra Historii Wychowania i Pedeutologii

e-mail: joanna.sosnowska@uni.lodz.pl 